\title{
PEDAGOGY OF ACTION: \\ A COMPARATIVE ANALYSIS OF V. A. LAY'S AND K. D. USHYNSKY'S PEDAGOGICAL WORK
}

Boichevska Ilona, PhD in Pedagogy, Associate Professor, Associate Professor of Foreign Languages Department, Pavlo Tychyna Uman State Pedagogical University.

ORCID: 0000-0001-8371-8947

E-mail: boy_ilona@ukr.net

Veremiuk Liudmyla, PhD in Pedagogy, Associate Professor, Associate Professor of the Foreign Languages Department, Pavlo Tychyna Uman State Pedagogical University.

ORCID: 0000-0002-6221-419X

E-mail: lyudmila.leoni@ukr.net

The article presents a comparative analysis of the ideas of the German pedagogue V. A. Lay and the national pedagogue K. D. Ushynsky. It has been determined that didactics occupies a special place in both pedagogues' heritage. The development of ideas of "school of action" in pedagogical theory and practice of Ukraine has been analyzed. In the result of the conducted analysis of national scientists' pedagogical ideas authors show that the development of "pedagogy of action" in national pedagogical science in the late $19^{\text {th }}$ - early $20^{\text {th }}$ century was closely connected with the socio-political movement in Ukraine. Much attention has been paid to the influence of pedagogical principles of the "school of action" on the pedagogical theory and practice of Ukraine in the specified period.

Keywords: pedagogy of action, school of action, psychic and physical nature, labour activity, mental development, attention, observation, nature-based learning.

\section{ПЕДАГОГІКА ДІї: ПОРІВНЯЛЬНИЙ АНАЛІЗ ПЕДАГОГІЧНОЇ ТВОРЧОСТІ В. А. ЛАЯ ТА К. Д. УШИНСЬКОГО}

Бойчевська Ілона, кандидат педагогічних наук, доцент, доцент кафедри іноземних мов, Уманський державний педагогічний університет імені Павла Тичини.

ORCID: 0000-0001-8371-8947

E-mail: boy_ilona@ukr.net

Веремюк Людмила, кандидат педагогічних наук, доцент, доцент кафедри іноземних мов, Уманський державний педагогічний університету імені Павла Тичини.

ORCID: 0000-0002-6221-419X

E-mail: lyudmila.leoni@ukr.net

Стаття присвячена дослідженню педагогічного спадку німецького педагога-реформатора В. А. Лая та вітчизняного педагога-новатора К. Д. Ушинського. Здійснено порівняльний аналіз ідей двох провідних науковиів. Визначено, щчо особливе місие у спадщині обох педагогів займає дидактика. Досліджено, що не мени важливе значення має трудова діяльність, яка виступає необхідним засобом розумового, фізичного й духовного розвитку учнів. Автори наголошують, що обидва педагоги приділяли значну увагу рефлексам, щзо покладені в основу педагогіки дї. 
Зазначено, щуо провідною умовою навчання виступав принщип природовідповідності. Багато уваги було приділено впливу педагогічних принципів «школи дії» на педагогічну теорію та практику Украӥни у зазначений період. Доведено, щчо украйнський педагог і вчений К. Уиинський різнобічно вивчав психічну та фізичну природу дитини, враховуючи досвід зарубіжних педагогівреформаторів. Окрім того, він зібрав і систематизував усе, щзо пов'язано з життям дитини, а також визначив закони, підпорядковані тілу, і створив на иій основі педагогіку. У свойх наукових прачях педагог розвивав ідеї шкільної громади, яка моделювала природне та соціальне середовище, в якому учень вчиться узгоджувати свої дії із законами довкілля. Вчений зазначав, щчо фізична прачя - ие корисний та приємний відпочинок після розумової, на прикладі досвіду багатьох установ Німеччини, де учні у вільний час займалися загальною трудовою діяльністю, садівництвом, ремонтом книг тощяо. К. Ушинський втілив основні ідеї В. А. Лая у практику, зокрема ті, щуо базуються на спостереженні. Порівняльний аналіз дозволив зробити висновок, щьо більщість украӥнських педагогів або вивчали та розробляли проблеми педагогіки дї̈ у свойх теоретичних роботах, або безпосередньо використовували педагогіку дії у своїй практичній діяльності.

Ключові слова: педагогіка дії, школа дї, трудова діяльність, духовний розвиток, рефлекси, увага, спадковість, принции природовідповідності.

At the turn of the XIX-XX centuries a new didactic concept, which was based on the first achievements of psychology on child development and the forms of educational activities organization began to form. This stage in the development of didactics coincided with the stage of general renewal of all aspects in the life of most developed countries, both in Europe and in America, including the reform of traditional pedagogical systems that did not meet the challenges of modern times. In the mainstream of reform pedagogy, simultaneously, in many countries, a child-oriented didactic concept was born, the distinctive feature of which can be expressed in the pedagogical formula "Vom Kindeaus" - "based on the child', proposed by the Swedish teacher Ellen Kay (1849-1926) in the book "The Age of the Child". Adherents of this concept distinguished the call to develop creative forces in the child. They believed that the child's experience and personal experience accumulation should play a leading role in upbringing, and therefore the main examples of the realization of the child-oriented concept were also called the theory of free education. A great contribution to the development of the child-oriented didactic concept was made by teachers and psychologists from different countries who created their own pedagogical concepts and schools: the Italian psychiatrist and teacher M. Montessori (1870-1952), the German scientist V. A. Lay (1862-1926), the Austrian philosopher R. Steiner (1861-1925), the French psychologist A. Binet (1857-1911) and the teacher S. Frenet (1896-1966), American educator and psychologist D. Dewey (1859-1952) [1; 4].

So, the "new" pedagogy was spread in the world and in Ukraine, in particular, on the basis of which the entire education system was reformed. Representatives of this approach (A. Lay, E. Maiman) for the first time were purposefully engaged in the comprehensive study of the child, as well as in the introduction of new experimental research method and search for effective ways of building relationships between teacher and student, which would contribute to the realization of developmental opportunities and creative potential of each child.

The current stage of Ukraine's education development reflects changes in socioeconomic and political life. The main directions of education development, defined by the State National Program "Education" ("Ukraine of the $21^{\text {st }}$ Century"), the National Doctrine of Education Development of Ukraine provides educational system modernization, which requires a number of measures, namely: refusal from authoritarian pedagogy; creation of 
conditions for an active, responsible, creative, independent personality development; providing conditions for realization and self-realization of the essential forces of the child in different types of his activity. In our opinion, such modernization changes in school education can be implemented with the help of study, systematization and putting into practice the ideas of pedagogical experience of national and foreign educators of the past. Particular attention of modern researchers of the history of pedagogy is attracted by the Renaissance and Enlightenment epochs, which are marked by the origin and development of humanistic ideas. In this context, there is interest in reformist pedagogy.

The paper used theoretical research methods, such as analysis and comparison of academic and pedagogical studies connected with the topic of this research and content analysis of research materials.

Progressive ideas, scientific-pedagogical and creative heritage of the representatives of the studied period became the subject of scientists' study and were reflected in the dissertations of I. M. Bakalenko, Yu. M. Korneiko (K. D. Ushynsky), A. V. Stepanenko (E. Maiman). However, V. A. Lay's works were studied in accordance with experimental pedagogy by such scientists as T. M. Petrova, L. O. Lysenko, T. O. Kravtsova and A. M. Rastygina.

In modern conditions, it is necessary to compare the ideas of national and foreign pedagogues, so that to be ready to implement these ideas into practice. Therefore, the aim of the article is to investigate V. A. Lay's pedagogical heritage and to carry out a comparative analysis of the ideas of the German innovator and national pedagogue K. D. Ushynsky.

Didactics occupy a special place in V. A. Lay's (1862-1926) and K. D. Ushynsky's (1824-1871) pedagogical heritage. Education, according to the native pedagogue Ushynsky, should solve two main tasks - educational and instructional. The educational task lies in the complete acquisition of knowledge about nature and society, which are necessary for a person to improve social life. The pedagogue believed that instructional task was to develop students' outlook [10, p. 327]. In his opinion, education should be activity-based. V. A. Lay also paid great attention to activity-based learning. He substantiated the idea of a pedagogy of action, which involved practical, creative activity. This approach to learning played a positive role in the fight against verbalism. V. A. Lay also contributed to the fact that with the help of didactic experiment he sought to determine the conditions of education success and justify the system of its methods and means [4, p. 184].

Both Lay and Ushynsky considered labour to be of great educational importance. We can evidence that from an article by K. D. Ushynsky, "Labor in its Mental and Educational Meaning", published in 1860 in the periodical No. 7, "Journal of the Ministry of National Education". In it, the author emphasized the dominant role of labour in the formation of human moral qualities. He put forward the idea of the active human nature and psyche, the fundamental importance of labour in the development of personality. This idea still remains relevant for modern pedagogy and practice. In this regard, he wrote: "Only inner, spiritual, life-giving power of labour is the source of human dignity and at the same time both morality and happiness" [10, p. 108]. This value of labour, according to K. D. Ushynsky is rooted in its mental basis, while the psychological law of labour lies in the fact that pleasure must be balanced with labour, no matter how high and noble it is. With the word "pleasure" the pedagogue understands the enjoyment of art, generosity, patriotism, love for humanity, family happiness. The Ukrainian teacher claims labour to be the only accessible thing on the earth 
and the only worthy thing of mankind happiness. Upbringing, in his opinion, should develop a person's habit and love to work, give the opportunity to find a 'beloved' job. Another important consequence for pedagogy, which derives from the psychological significance of labour, is that upbringing must not only develop the person's mind and give knowledge but also ignite the desire for work. In order to love labour, first of all, it is necessary for a person to have a sensible outlook on life. K. D. Ushynsky connected labour not only with upbringing but also with teaching. He noted that teaching of every school subject should inevitably take place in such a way that the pupil could deal with as much labour as he can overcome. The scientist stated that physical work is a useful and enjoyable rest after the mental one, using as an example the experience of many institutions in Germany, where the pupils were engaged in general labour activities, gardening, framing books, etc. in their spare time [10, p. 104120]. So, labour, according to K. D. Ushynsky, was the highest form of human activity, whereas the desire for activity is an inherent property of a person. Labor serves as the key to a person's spiritual development. Labour activity was a necessary condition for the harmonious physical, mental, moral and aesthetic development of a person. Labour serves as the key to a person's spiritual development. Labour activity was a necessary condition for the harmonious physical, mental, moral and aesthetic development of a person [3, p. 99-106].

The German educator V.A. Lay had the same opinion. In "Experimental Didactics" (1903), he outlined the views of reforming the school, where Labor Training was not only an educational subject but also the principle of all disciplines teaching. According to V.A. Lay, manual labour in a public school should become a tool for students' mental, physical and spiritual development of [4, p. 444].

K. D. Ushynsky was aware of the European experience in educational activity organizing in schools. While attending the Swiss schools from 1862 to 1867 , he noted that their pedagogical theory and practice were based on the laws of physiology and psychology. After all, it is not uncommon to find tutors who have extensive knowledge of anatomy and physiology due to the knowledge they have gained from foreign literature. One can find some notes on the importance of physiology and psychology knowledge for educators written by K. D. Ushynsky: "Reading physiology, we see on every page that there is a wide opportunity to influence the physical development of the individual, and even more opportunities for the consistent development of the human race. When we look at the psychic facts taken from different theories, we are even more amazed by the opportunity to have a tremendous influence on the development of the person's mind, feelings and will, and we are also amazed by the scantiness of this opportunity, which has already been used by upbringing" [10, p. 202-208]. Thus, one can conclude that the national pedagogical theory and practice in the late 19th - early 20th centuries borrowed knowledge of physiology and psychology from foreign editions.

The theory of the "school of action" of the German pedagogue V. A. Lay was also based on the knowledge of physiology and psychology. Books and explanations of the teacher were not the starting point and the means of realization of pedagogy of action for him. Only interest, will, labour and the child's harmonious and diverse life were the main factors. In his opinion, education should be based on a sequence of actions such as perception, mental processing of the received information, the external expression of ideas through the description, drawing, experiments, dramatization and other means. That is why manual labour became a teaching principal in V. A. Lay's system which promotes learning and upbringing. 
After all, labour is a necessary endpoint of the natural process of interconnected reactions. A special role was assigned by V. A. Lay to the third component of his triad - expression, which is an action aimed at adapting the child to environmental conditions, including social ones. Forming such an adaptation in a child was the main task of the school of action $[5 ; 6]$.

Both V. A. Lay and K. D. Ushynsky focused on pedagogues' attention on psychology knowledge. He emphasized that the teacher should be a psychologist because of his profession because he studies the child, his abilities, inclinations, notices the development of his mind and directs this development, forms a character, that is "every minute he is in the sphere of psychological phenomena" [10, p. 338]. Both educators considered taking into account the psychological characteristics of the child to be one of the most important conditions for proper educational work organization. According to V. A. Lay, psychology teaches that feelings, imagination, will and thinking generate movement, take on forms of reaction. Central motor processes extend to the motor nerves and trigger the muscles of the sensory organs when perceived. In particular, he noted that the observation of any object causes eye concentration, according to which we get a visual image of some clarity. If this image does not satisfy us in comparison with the true prototype, the brain sends a new impulse, which forces to improve the installation of the visual apparatus, and then this image becomes clearer, that is, the perception is improved due to external expression [7, p. 45]. So, in V. A. Lay's opinion, the main education principle is the principle of action, which makes the teacher maximize the use of all children's reactions to the environment influence and develops all forms of students' activity. In the child's actions, one can find an expression of his ideas about the world. Since actions are based on the innate or acquired reflexes in the process of life experience, upbringing and learning must first be based on them [2, p. 503].

As stated by S. L. Soloveychyk in the book "The Time of Learning. The Life of Wonderful Teachers", the opportunity to act in different directions appeared in the 1960s. It was during this time that capitalist entrepreneurship developed rapidly, and all population needed "active people" and valued initiative, a lively character, a bright and accurate word. According to the researcher, K. D. Ushynsky just expressed this general need for action in his articles, namely, in the education of people of action. He sought to teach students to act, to be active, attentive, interested and energetic in every lesson. S. L. Soloveychyk claims K. D. Ushinsky's pedagogy to be the pedagogy of action, the theory of an energetic and industrious person upbringing, and we completely agree with him [9, p. 137-139].

Both educators paid great attention to the importance of skills. In particular, K. D. Ushynsky wrote: "Everyone who taught children to write and read noticed without any doubts the important role of skills acquired by the student through exercises. These skills are slowly rooted in the student's nervous system in the form of reflexive unconscious or semiconscious movements. It may take a long time when the child understands how to do something, the same action slowly loses the character of consciousness and becomes a subconscious or semi-conscious reflex. Only when reading and writing have become a mechanism, a habit and an unconscious reflex for the child, the child's consciousness and will are ready to acquire new, higher knowledge and skills" [10, p. 233]. That is, according to the pedagogue, the habit is rooted through the repetition of any action. It should be repeated until the reflexive capacity of the nervous system begins to be reflected in the action and until the tendency for this action is established in the nervous system. Therefore, repeating the same actions is a prerequisite for establishing a habit. K. D. Ushynsky noted that this repetition, 
especially at the beginning, should be frequent if possible; but one should bear in mind the property of the nervous system to fatigue and restore its strength. If the actions are repeated so often that the nerves do not have time to recover, this can only irritate the nervous system and not establish a habit. The teacher called the periodicity of actions one of the essential conditions of habit formation because this periodicity is visible in the nervous system functioning. At the same time, it is important to have a proper distribution of lessons [10, p. 234-235]. The scientist's instructions confirm this: "If we want to put any skill into practice, we should offer some kind of action. We need to think about this course of action and express it in a simple short rule, and only then demand this rule be followed". After all, the power of habit is the power of upbringing [6, p. 234-235].

K. D. Ushynsky claimed attention to be a special factor in the child's education and upbringing. In his opinion, we need attention in order to turn impression into a feeling. He called this process "the only door through which the impressions of the outside world, or more precisely, the states of the nervous organism, evoke feelings in the soul" [10, p. 241250]. The pedagogue noted that education should be based on specific images obtained by children from the outside world. Education goes through two main stages. The first one is divided into three levels. The first level focuses on the fast perception of the objects or phenomena of the outside world by children under the teacher's guidance. The second level lies in the fact that students compare and contrast perceived images and thus produce preliminary concepts with the help of the teacher. At the third level, the teacher explains these concepts, separating the basic from the secondary and bringing the knowledge gained into the system. The second stage begins with the generalization of the material taught by the teacher and work is done to consolidate the acquired knowledge and skills [10, p. 330]. These stages are quite similar to V. A. Lay's triad of actions - perception, mental acquisition of the perceived and external display of the produced ideas through drawing, Layout, dramatic act or any other action that contributed to the child's adjustment to the environment.

K. D. Ushynsky put forward the principle of nature-based learning, that is, the correspondence of learning to the nature of the child. He saw this correspondence in the early start of learning. He stated: "If you begin to teach a child before he or she is psychologically ready for learning, or to teach a subject whose content does not correspond the age, you will inevitably encounter such obstacles in the child's nature that only time can overcome" [7, p. 329].

The native pedagogue considered promoting the free development of children's abilities to be an important prerequisite for nature-based learning, taking into account the specific features of this development at different age stages. In order to implement the principle of nature-based learning, K. D. Ushynsky pointed to the need to build an educational process based on knowledge of psychology, physiology and human anatomy. In his opinion, the nature-based pedagogy lies in taking into account the features of the child's psychophysical development. The basic law of child nature, K. D. Ushinsky argued, can be expressed like this: a child needs activity and is tired not because of activity, but of its monotony and one-sidedness. The educator thought that the essence of the child's natural state is inactivity, mobility, in the pursuit of environmental awareness, and noted that this "instruction of nature" should be guided by the teacher [7, p. 182-201]. The principle of nature-based learning was also the basis of V. A. Lay's pedagogical concept. He regarded nature-based learning as a pedagogical principle, which required the construction of an 
educational process based on the child nature. According to the scientist, nature-based learning is also one of the fundamental principles of school reform. For example, in the book "School of Action. School Reform in Accordance with the Requirements of Nature and Culture" the teacher developed the ideas of a school community, which modelled natural and social environment, where the student learns to coordinate his actions with the environment laws [7, p. 156].

One may also trace the ideas of heredity influence on child development in V. A. Lay's and K. D. Ushinsky's works. While analyzing the biological and social factors of education and their impact on the child's body and soul, German educator took into account the following inheritance factors: individual (inherited inclinations, instincts), parents (illness, crime), sisters and brothers (number, age, illness etc.), ancestors, race [5, p. 65]. K. D. Ushinsky also noted the fact of hereditary transmission of certain diseases. The pedagogue believed that the child's inclination to this or that kind of activity the inheritance can also be inherited. However, external influence, that is, the environment and education and not the heredity make the decisive influence on the personal development and the formation of human qualities [3, p. 74-75].

Thus, having carried out a comparative analysis of pedagogical ideas of the German pedagogue-innovator V. A. Lay and the national pedagogue K. D. Ushynsky, we have come to the conclusion that at the end of the 19th century, when capitalist entrepreneurship developed rapidly, the need for action in its various manifestations appeared. In particular, the task of education was to educate people of action, to achieve vigour, activity, participation in lessons. The pedagogues (K. D. Ushynsky and V. A. Lay) considered labour training to be not a separate subject, but a necessary means of students' mental, physical and spiritual development. Both pedagogues paid great attention to the reflexes that are the basis of the school of action. They advised to build the educational process on the basis of perception, mental acquisition of the perceived and work on the acquired knowledge and skills consolidation (K. D. Ushynsky) or the external reflection of the produced ideas (V. A. Lay). According to scientists, the leading educational condition was the principle of nature-based learning. German and national educators determined heredity to be one of the biological factors of education and upbringing. However, they noted that the environment still has an important impact on child development.

Further research should be aimed at investigation of implementation methodology of the best ideas of pedagogy of action not only in Ukraine and Germany but in other foreign countries as well.

\section{СПИСОК ВИКОРИСТАНИХ ДЖЕРЕЛ}

1. Basic didactic concepts. URL: https://testmyprep.com/subject/pedagogy/basic-didactic-concepts-pedagogy.

2. Веремюк Л. Л. Педагогіка дії як один із напрямків реформаторської педагогіки: історичний аспект. Рідна школа. 2009. № 4(952). С. 74-77.

3. Гончаров Н. К. Педагогическая система К. Д. Ушинского. М.: Педагогика, 1974. 272 с.

4. Енциклопедія освіти / Акад. пед. наук України; [гол. ред. В. Г. Кремень]. К.: Юрінком Інтер, 2008. $1040 \mathrm{c}$.

5. Hopf Caroline. Die experimentelle Pädagogik: empirische Erziehungswissenschaft in Deutschland am Anfang des 20. Jahrhunderts. Bad Heilbrunn/Obb.: Klinkhardt, 2004. 344 s. URL: http://www.ulb.tudarmstadt.de/tocs/120906848.pdf.

6. Lay W. A. Experimentelle Pädagogik als neudeutsche Erziehung durch Lebensgemeinschaft und Tat. Sonde. Pädagogische Monatsschrift. 1917. S. 164-172.

ISSN 2706-6258 
7. Lay W. A. Tatschule als natur- und kulturgemäße Schulreform. Zugleich Anklage und Mahnruf. Osterwiek/Harz, 1921. $98 \mathrm{~s}$.

8. Педагогические идеи К. Д. Ушинского / [редактор О. Свердлова]. М.: Знание,1971. 80 с.

9. Соловейчик С. Л. Час ученичества. Жизнь замечательных учителей. изд. 2-е. М.: Дет. лит., 1972.

10. Ушинський К. Д. Вибрані педагогічні твори: в 2-х т. / [за ред. О. І. Пискунова]. К.: Рад. школа, 1983. 488 c.

\section{REFERENCES}

1. Basic didactic concepts. URL: https://testmyprep.com/subject/pedagogy/basic-didactic-concepts-pedagogy.

2. Veremiuk, L. (2009). Pedahohika diyi yak odyn iz napryamkiv reformators'koyi pedahohiky: istorychnyy aspect. [Pedagogy of action as one of the directions of reform pedagogy: the historical aspect]. Ridna shkola. Kyiv [in Ukrainian].

3. Honcharov, N. K. (1974). Pedagogicheskaya sistema K. D. Ushinskogo. Moscow: Pedagogika [in Russian].

4. Entsyklopediya osvity. (2008). V. Kremen' (Ed.) Kyiv: Yurinkom Inter [in Ukrainian].

5. Hopf, C. (2004). Die experimentelle Pädagogik: empirische Erziehungswissenschaft in Deutschland am Anfang des 20. Jahrhunderts. URL: http://www.ulb.tu-darmstadt.de/tocs/120906848.pdf.

6. Lay, W. A. (1917). Experimentelle Pädagogik als neudeutsche Erziehung durch Lebensgemeinschaft und Tat. Pädagogische Monatsschrift, 164-172.

7. Lay, W. A. (1921). Tatschule als natur- und kulturgemäße Schulreform. Zugleich Anklage und Mahnruf. Osterwiek/Harz.

8. Pedagogicheskiye idei K. D. Ushinskogo. (1971). O. Sverdlova (Ed.). Moscow: Znaniye [in Russian].

9. Soloveychik, S. L. (1972). Chas uchenichestva. Zhizn' zamechatel'nykh uchiteley. Moscow: Detskaya literature [in Russian].

10. Ushyns'kyy, K. D. (1983). Vybrani pedahohichni tvory. (Vol. 1-2). O. I. Pyskunov (Ed.). Kyiv: Radyanska shkola [in Ukrainian]. 